\title{
Erratum to: 'Phosphoproteomic analysis reveals Smarcb1 dependent EGFR signaling in Malignant Rhabdoid tumor cells'
}

\author{
Jonatan Darr ${ }^{1}$, Agnes Klochendler ${ }^{1}$, Sara Isaac ${ }^{1}$, Tamar Geiger ${ }^{2}$ and Amir Eden ${ }^{\text {** }}$
}

Unfortunately, the original version of this article [1] contained an error. An author's name was spelt incorrectly. It was spelt as Tami Geiger when it should have been spelt as Tamar Geiger instead which is the correct spelling and included here in this erratum.

\begin{abstract}
Author details
'Department of Cell and Developmental Biology, The Alexander Silberman Institute of Life Sciences, The Hebrew University of Jerusalem, Jerusalem, Israel. 'Department of Human Molecular Genetics and Biochemistry, Sackler Faculty of Medicine, Tel Aviv University, Tel Aviv, Israel.
\end{abstract}

Received: 8 February 2016 Accepted: 8 February 2016

Published online: 12 February 2016

\section{Reference}

1. Jonatan D, Agnes K, Sara I, Tamar G, Amir E. Phosphoproteomic analysis reveals Smarcb1 dependent EGFR signaling in Malignant Rhabdoid tumor cells. Mol Cancer. 2015;14:167.

\footnotetext{
*Correspondence: eden@vms.huji.ac.il

1Department of Cell and Developmental Biology, The Alexander Silberman Institute of Life Sciences, The Hebrew University of Jerusalem, Jerusalem, Israel

Full list of author information is available at the end of the article
}

Submit your next manuscript to BioMed Central and we will help you at every step:

- We accept pre-submission inquiries

- Our selector tool helps you to find the most relevant journal

- We provide round the clock customer support

- Convenient online submission

- Thorough peer review

- Inclusion in PubMed and all major indexing services

- Maximum visibility for your research

Submit your manuscript at

www.biomedcentral.com/submit

\section{() Biomed Central}

